\title{
Production performance of crossbred dairy cows fed palm kernel cake in feedlots
}

\section{Desempenho produtivo de vacas leiteiras mestiças alimentadas com torta de dendê}

\author{
Leidiane Reis Pimentel ${ }^{1 *}$; Fabiano Ferreira da Silva ${ }^{2}$; Robério Rodrigues Silva ${ }^{2}$; \\ Antonio Ferraz Porto Junior ${ }^{1}$; Evely Giovanna Leite Costa ${ }^{1}$; Alex Resende Schio ${ }^{1}$; \\ Dicastro Dias de Souza ${ }^{1}$; Eli Santana de Oliveira Rodrigues ${ }^{1}$; Gonçalo Mesquita da \\ Silva $^{1}$; Murilo de Almeida Menezes ${ }^{1}$
}

\begin{abstract}
Resumo
Objetivou-se avaliar o efeito da inclusão de torta de dendê na dieta sobre o consumo, digestibilidade e desempenho de vacas mestiças em lactação. Foram utilizadas 12 vacas mestiças Holandês x Zebu, distribuídas em três Quadrados Latinos 4 x 4, nos seguintes tratamentos: controle (sem inclusão de torta de dendê na dieta); inclusão de 50,0 $\mathrm{g}$ de torta de dendê.. $\mathrm{kg}^{-1}$ na matéria seca total; $100,0 \mathrm{~g}$ de torta de dendê. $\mathrm{kg}^{-1}$ na matéria seca total; $150,0 \mathrm{~g}$ de torta de dendê. $\mathrm{kg}^{-1}$ na matéria seca total. Não houve efeito do uso de torta de dendê sobre os consumos de matéria seca, fibra em detergente neutro corrigida, carboidratos não fibrosos e nutrientes digestíveis totais. Foi observado efeito linear crescente nos consumos de proteína bruta e extrato etéreo. A inclusão da torta de dendê na dieta não influenciou os coeficientes de digestibilidade da matéria seca, proteína bruta, e extrato etéreo, carboidratos não fibrosos, bem como a produção de leite, eficiência alimentar e variação do peso corporal. A produção de leite corrigida teve um efeito linear crescente com a inclusão da torta de dendê. A inclusão de $150 \mathrm{~g}$ de torta de dendê na dieta de vacas leiteiras não influenciou o consumo, o desempenho dos animais e a composição do leite.
\end{abstract}

Palavras-chave: Coprodutos. Digestibilidade. Consumo. Composição do leite.

\begin{abstract}
The objective of this study was to evaluate the effect of inclusion of palm kernel cake in the diet on dietary intake and digestibility and performance of lactating crossbred cows. Twelve Holstein $\times$ Zebu crossbred cows were distributed in three $4 \times 4$ Latin squares with the following treatments: control (no inclusion of palm kernel cake in the diet); inclusion of $50 \mathrm{~g}$ of palm kernel cake $\mathrm{kg}^{-1}$ in the total dry matter, $100 \mathrm{~g}$ of palm kernel cake $\mathrm{kg}^{-1}$ in the total dry matter, and $150 \mathrm{~g}$ of palm kernel cake $\mathrm{kg}^{-1}$ in the total dry matter. There was no effect of palm kernel cake on the intakes of dry matter, corrected neutral detergent fiber, non-fibrous carbohydrates, and total digestible nutrients. The intakes of crude protein and ether extract increased linearly. Inclusion of palm kernel cake in the diet did not influence the digestibility coefficients of dry matter, protein, ether extract, and non-fibrous carbohydrates, or milk
\end{abstract}

1 Discentes de Doutorado, Programa de Pós-Graduação em Zootecnia, Universidade Estadual do Sudoeste da Bahia, UESB, Itapetinga, BA, Brasil. E-mail: leidyrp@yahoo.com.br; ferrazporto@hotmail.com; evelygiovanna@hotmail.com; resendezoo@ hotmail.com; dico111_3@hotmail.com; eli.uesb@hotmail.com; gon_zootecnia23@hotmail.com; dddmeneses@msn.com

2 Profs. Drs., Programa de Pós-Graduação em Zootecnia, UESB, Itapetinga. BA, Brasil. Bolsista de Produtividade do CNPq. E-mail: ffsilvaeusb@hotmail.com; rrsilva.uesb@hotmail.com

* Author for correspondence 
production, feed efficiency, and body weight change. Fat-corrected milk yield increased linearly with the addition of palm kernel cake. Inclusion of up to $150 \mathrm{~g}$ of palm kernel cake in diets did not influence the dietary intake and performance of lactating cows or the composition of their milk.

Key words: By-product. Digestibility. Intake. Milk composition.

\section{Introduction}

Brazil has a great potential for the production of diversified foods, generating many types of residues and by-products derived from agribusiness. However, biodiesel production, a booming activity of great interest worldwide, may increase the availability of by-products even further, with this resulting from the extraction of oil from oilseeds in the biodiesel production chain. The majority of cakes or meals from oilseeds used in biodiesel production in Brazil have the potential to be used in animal feeding (ABDALLA et al., 2008).

The production of palm kernel cake involves grinding the palm kernel, followed by pressing, which may or may not have the intermediate phase of peeling and cooking. During the pressing stage, the raw palm kernel oil is progressed to refinement stage and the residual cake is chilled and stored in a storage unit (SUE, 2001).

According to Cunha et al. (2012), palm kernel cake contains $15.42 \%$ of crude protein in the dry matter, a nutrient that is utilized by the rumen microflora. According to Bringel et al. (2011), the palm kernel cake has its own characteristics as a roughage feedstuff that are attributed to its high neutral detergent fiber content of $64.09 \%$ in the dry matter.

From the perspective of substitution of ingredients traditionally used in feeds, including palm cake in ruminant diets is an alternative for sustainable production systems (COSTA et al., 2010). However, the use of palm kernel cake in diets for lactating cows in the feedlot is not yet defined and should be studied thoroughly, aiming to determine and quantify the necessary percentage to meet the animal requirements, which can be achieved through research that estimates the voluntary intake and digestibility of by-products.
The objective of this study was to evaluate the inclusion of palm kernel cake in diets in feedlots of lactating cows on dietary intake, apparent digestibility of nutrients, milk yield and composition, and body weight change.

\section{Material and Methods}

The experiment complied with the ethical standards and was approved by the Ethics Committee on the Use of Animals (ECUA) under protocol no. 130/2016 of March 18, 2016. Twelve Holstein $\times$ Zebu ( $1 / 2$ to $3 / 4$ Holstein) cows were used in the experiment. Cows were at the third or fourth lactation stages, with previous production between 2,500 and $3,500 \mathrm{~kg}$, adjusted for 300 days, at an average of $64 \pm 13.32$ days in milk at the beginning of the experimental period. The twelve dairy cows were distributed into three $4 \times 4$ Latin squares, with the following treatments: control - no inclusion of palm kernel cake (PKC) in the diet; inclusion of 50 g PKC kg-1 total dry matter (TDM); $100 \mathrm{~g} \mathrm{PKC} \mathrm{kg}^{-1}$ TDM; and $150 \mathrm{~g} \mathrm{PKC} \mathrm{kg}^{-1}$ TDM.

The roughage utilized was sugarcane (Saccharum officinarum) variety RB 72454, treated with $1 \%$ of a mixture of urea and ammonium sulfate (9:1), in the experimental phase. Following recommendations of Santos et al. (2011) for a period of seven days before the onset of the experiment, cows received the roughage containing only $0.5 \%$ of the urea mix, aiming to adapt them to this component added to the roughage and thus prevent occasional intoxication.

The concentrate supplementation level (Table 1) was defined by balancing the diets to contain sufficient nutrients for maintenance, a body weight gain of $0.15 \mathrm{~kg}$ day $^{-1}$, and milk production of $15 \mathrm{~kg}$ day $^{-1}$, according to NRC (2001). This was based on the chemical composition data of sugarcane, corn, 
soybean meal, and palm kernel cake, evaluated before the experimental period.

The experiment started on September 24, 2012 and ended on December 09, 2012. There were four experimental periods with 19 days each; the first 14 days were used for acclimation. During each experimental period, roughage and supplements were collected for evaluation of chemical composition of the diets. The palm kernel cake, acquired from the company Óleos de Palma SA AGRO INDUSTRIAL, located in Taperoá - BA, Brazil, was analyzed chemically (Table 2).

Table 1. Proportions of the ingredients (dry matter basis).

\begin{tabular}{|c|c|c|c|c|}
\hline \multirow{2}{*}{ Ingredient (\%) } & \multicolumn{4}{|c|}{ Palm kernel cake level $\left(\mathrm{g} \mathrm{kg}^{-1}\right)$} \\
\hline & 0.00 & 50.00 & 100.00 & 150.00 \\
\hline Sugarcane & 684.00 & 649.20 & 610.10 & 575.00 \\
\hline Cornmeal & 227.40 & 221.60 & 219.40 & 213.30 \\
\hline Soybean meal & 70.80 & 65.90 & 62.00 & 56.90 \\
\hline Palm kernel cake & 00.00 & 43.00 & 91.60 & 138.50 \\
\hline Mineral salt ${ }^{1}$ & 10.10 & 10.20 & 10.10 & 10.20 \\
\hline Dicalcium phosphate & 5.00 & 4.20 & 3.10 & 2.10 \\
\hline Limestone & 2.50 & 3.20 & 3.50 & 3.80 \\
\hline
\end{tabular}

Table 2. Chemical composition of sugarcane, palm kernel cake, and the concentrate during the experimental periods.

\begin{tabular}{lcccccc}
\hline \multirow{2}{*}{ Component } & Sugarcane & Palm & \multicolumn{3}{c}{ Palm kernel cake level $\left(\mathbf{g ~ k g}^{-\mathbf{1}} \mathbf{\text { DM}}\right)$} \\
\cline { 5 - 7 } & + urea & kernel cake & $\mathbf{0 . 0 0}$ & $\mathbf{5 0 . 0 0}$ & $\mathbf{1 0 0 . 0 0}$ & $\mathbf{1 5 0 . 0 0}$ \\
\hline Brix $^{1}$ & 18.510 & - & - & - & - & - \\
Dry matter & 297.10 & 922.50 & 377.20 & 388.60 & 402.90 & 417.40 \\
Crude protein & 107.10 & 143.40 & 123.10 & 123.50 & 123.60 & 127.10 \\
Ether extract & 13.80 & 105.60 & 16.20 & 17.90 & 20.00 & 22.50 \\
NDFap & 585.40 & 656.30 & 446.50 & 432.70 & 438.80 & 447.90 \\
Acid detergent fiber & 485.80 & 464.20 & 382.90 & 384.60 & 394.20 & 377.00 \\
Non-fiber carbohydrates & 343.70 & - & 445.90 & 455.10 & 444.50 & 426.50 \\
Total carbohydrates & 867.50 & - & 851.20 & 848.90 & 847.00 & 840.50 \\
Lignin & 98.50 & 183.10 & 49.20 & 70.00 & 82.90 & 99.90 \\
\hline
\end{tabular}

NDFap - neutral detergent fiber corrected for ash and protein; ${ }^{1}$ Concentration of soluble sugars in the sugarcane.

The feed was supplied as a complete mixture twice daily, at $07.00 \mathrm{~h}$ and $15.00 \mathrm{~h}$, ad libitum so as to allow for $10 \%$ as refusals.

Milk yield was evaluated from the $15^{\text {th }}$ day to the $19^{\text {th }}$ day of each experimental period and was weighed two times per day. Milk samples ( $1 \%$ of the daily production) from the $1^{\text {st }}$ and $2^{\text {nd }}$ milking sessions (with the calf under the dam) on the $16^{\text {th }}$ day were collected for determination of protein content according to (INCT-CA) (DETMANN et al., 2012); fat, lactose, non-fat solids, and total solids as described by Pregnolato and Pregnolato (1985); and 
$3.5 \%$ fat corrected milk yield (CMY) according to Sklan et al. (1992), by using the following equation: $\mathrm{CMY}=(0.432+0.1625 \times \%$ milk fat $) \times$ milk yield in $\mathrm{kg}$ day $^{-1}$.

From days 15 to 19 of each experimental period, the supplied feed and the refusals were weighed to determine the intake and were sampled for chemical analyses. Samples of the refusals and of the supplied feed, sugarcane, and concentrate were frozen at $-20{ }^{\circ} \mathrm{C}$, subsequently thawed and pre-dried, and composite samples were formed per animal and per period based on dry weight. At the end of the experimental period, the samples were ground in a 1 mm screen mill, packed in lidded bottles, and stored for later analyses.

The dry matter (DM), crude protein $(\mathrm{CP})$, ether extract (EE), acid detergent fiber (ADF), neutral detergent fiber free of ash and protein (NDFap), lignin, and mineral matter (MM) contents of the diets were analyzed following to the standard analytical procedures of the Brazilian National Institute of Science and Technology in Animal Science (INCTCA) (DETMANN et al., 2012). The non-fiber carbohydrates (NFCs) in the samples that did not contain urea were calculated by using the equation proposed by Detmann and Valadares Filho (2010): $\mathrm{NFC}=100-(\% \mathrm{CP}+\% \mathrm{EE}+\%$ ash $+\%$ NDFap $)$, in which $\% \mathrm{CP}=$ crude protein content, $\% \mathrm{EE}=$ ether extract content, $\%$ ash $=$ ash content, and $\%$ NDFap $=$ concentration of neutral detergent fiber corrected for ash and protein. However, the NFC of the samples that contained urea was determined by using the following formula: $\mathrm{NFC}=100-\{(\% \mathrm{CP}-\% \mathrm{CPU}+$ $\% \mathrm{U})+\%$ ash $+\% \mathrm{EE}+\%$ NDFap $\}$, in which $\% \mathrm{CPU}$ $=$ crude protein from urea and $\% \mathrm{U}=$ urea content.

Total digestible nutrient (TDN) content was calculated according to NRC (2001): TDN $=$ DCP $+\mathrm{DEE} \times 2.25+\mathrm{DNDF}+\mathrm{DNFC}$, where DCP $=$ digestible crude protein, $\mathrm{DEE}=$ digestible ether extract, FDND = digestible neutral detergent fiber, and DNFC $=$ digestible non-fibrous carbohydrates.
Animals were weighed once daily at the beginning and three times at the end of each period to determine the body weight change achieved with each diet.

Feces were collected directly from the rectal ampulla at $08.00 \mathrm{~h}$ on the $16^{\text {th }}$ day and at $15.00 \mathrm{~h}$ on the $17^{\text {th }}$ day of each period. The collected feces were packed in plastic bags and stored at $-20^{\circ} \mathrm{C}$. At the end of the collection period, the samples of feces were thawed, dried in a forced-air oven at 55 ${ }^{\circ} \mathrm{C}$ for 72 to $96 \mathrm{~h}$, and then ground in a mill with 1-mm screen sieves and stored for later analyses. Indigestible neutral detergent fiber (iNDF), obtained after incubation of the feed samples, refusals, and feces, was used as an internal marker (VALENTE et al., 2011) to estimate digestibility. The apparent digestibility (D) of the nutrients was determined by using the formula described by Silva and Leão (1979): $\mathrm{D}=[(\mathrm{kg}$ nutrient intake $-\mathrm{kg}$ nutrient output) $/ \mathrm{kg}$ nutrient intake] $\times 100$.

Data were analyzed by analysis of variance and regression using the System for Statistical and Genetic Analysis (SAEG, 2007).

Data were analyzed according to the following statistical model:

$$
\text { Yijkl }=\mu+\mathrm{Ti}+\mathrm{Qj}+\mathrm{Pk}+\mathrm{A}(\mathrm{j}) 1+\mathrm{TQij}+\text { eijkl, }
$$

where Yijkl $=$ experimental response; $\mu=$ general constant; $\mathrm{Ti}$ = fixed effect of treatment $\mathrm{i}$; $\mathrm{Qj}=$ random effect of Latin square $\mathrm{j} ; \mathrm{Pk}=$ random effect of period $\mathrm{k} ; \mathrm{A}(\mathrm{j}) \mathrm{l}=$ random effect of animals nested in Latin square $\mathrm{j}$; TQij = random effect of the interaction between treatment $j$ and Latin square $\mathrm{i}$; and eijkl = random error associated with each observation, with normal distribution assumption $(0 ; \sigma 2)$

For all the tested variables, linear and quadratic effects of treatment (Ti) were assessed, and the critical level of significance adopted was 0.05 . 


\section{Results and Discussion}

The use of palm kernel cake had no effects (P $>0.05)$ on DM intake, (152.1 $\mathrm{g}$ day $^{-1}$; Table 3$)$, in spite of the high fiber, lignin, and EE contents of the cake, which was included in the diet at the rates of up to $150.0 \mathrm{~g} \mathrm{~kg}^{-1}$.

Table 3. Intakes of dry matter and nutrients by dairy cows fed with diets supplemented with varying levels of palm kernel cake.

\begin{tabular}{lccccccc}
\hline \multirow{2}{*}{ Intake } & \multicolumn{3}{c}{ Palm kernel cake level $\left(\mathbf{g ~ k g}^{-\mathbf{1}}\right)$} & \multirow{2}{*}{ Eq. } & \multirow{2}{*}{ CV \% } & P-value \\
\cline { 2 - 5 } & $\mathbf{0 . 0 0}$ & $\mathbf{5 0 . 0 0}$ & $\mathbf{1 0 0 . 0 0}$ & $\mathbf{1 5 0 . 0 0}$ & & & \\
\hline Dry matter & 147.10 & 148.90 & 157.40 & 155.20 & 152.10 & 7.93 & 0.133 \\
Dry matter (\% BW) & 3.08 & 3.12 & 3.24 & 3.34 & 3.20 & 11.93 & 0.324 \\
Crude protein & 18.20 & 18.40 & 19.60 & 19.90 & 1 & 8.77 & 0.037 \\
NDFap & 65.70 & 64.90 & 69.80 & 69.80 & 67.50 & 8.57 & 0.082 \\
NDFap (\% BW) & 1.37 & 1.36 & 1.43 & 1.500 & 1.41 & 13.06 & 0.242 \\
Ether extract & 2.40 & 2.60 & 3.10 & 3.40 & 2 & 8.15 & 0.004 \\
NFC & 65.50 & 67.20 & 69.00 & 65.80 & 65.90 & 7.74 & 0.331 \\
TDN & 95.60 & 98.60 & 102.20 & 103.10 & 99.90 & 7.87 & 0.096 \\
\hline
\end{tabular}

Eq. - regression equation; CV - coefficient of variation; BW - body weight; NDFap - neutral detergent fiber corrected for ash and protein; NFC - non-fibrous carbohydrates; TDN - total digestible nutrients; ${ }^{1} \hat{\mathrm{Y}}=1.742+0.0637 \mathrm{x}, \mathrm{R}^{2}=0.91 ;{ }^{2} \hat{\mathrm{Y}}=0.198+0.036 \mathrm{x}$, $\mathrm{R}^{2}=0.99$.

Feed intake usually increases as body weight (BW) increases; therefore, it is more convenient to express this variable in relation to the animal BW. In this study, there were no effects of palm kernel cake $(\mathrm{P}>0.05)$ on $\mathrm{DM}$ intake in relation to $\mathrm{BW}$, averaging 3.20\%. According to Mertens (1994), expressing intake in relation to the metabolic body weight or as percentage of body weight depends on whether the intake limitation results from an energy factor or filling, respectively. This effect can be explained by the increased NDF of the diets supplemented with palm kernel cake, which may have caused a "rumen-fill effect" on the animals, limiting the intake of dry matter. This finding is in contrast to the results obtained in this study, likely due to the quality of the by-product used that varied in the type of oil extraction and raw material.

Crude protein intake increased linearly $(\mathrm{P}<$ 0.05 ) by $0.0637 \mathrm{~kg}$ with every $1 \%$ palm kernel cake added to the diet. This increase may be related to the good acceptance of the palm cake, since the diets had similar CP contents (Table 2). The intakes of NDFap, expressed in $\mathrm{kg} \mathrm{day}^{-1}$, and $\% \mathrm{BW}$ were not influenced by the addition of palm kernel cake in the diet $(\mathrm{P}>0.05)$, although this ingredient is a by-product with high levels of NDFap (65.63\%), a fraction negatively correlated with energy, as measured by the physical mechanisms of satiety (MERTENS, 1994). As the level of the cake in the diet was increased, the roughage content in the diet decreased to balance the energy, as can be observed for the NDFap of the diets presented in Table 2.

In a national literature review on the overall average NDF intake in relation to live weight, Souza et al. (2008) found 1.6\% BW. The result obtained in the present study for NDFap intake as a function of BW was $1.41 \%$, with no difference found between the tested levels $(\mathrm{P}>0.05)$.

The treatments had a positive linear effect $(\mathrm{P}<$ $0.05)$ on EE intake, which increased by 0.036 with every unit of palm kernel cake added to the diet. 
The increase in EE intake was expected, given the elevated ether extract content of $10.56 \%$ in the DM (Table 2) present in the palm kernel cake. Dietary EE levels greater than $50 \mathrm{~g} \mathrm{~kg}^{-1}$ may compromise the dry matter intake, either by regulatory mechanisms that control feed intake or by the limited ability of ruminants to oxidize fatty acids (PALMQUIST; MATTOS, 2006).

Maciel et al. (2012) used four levels of palm kernel cake $\left(0,119,229\right.$, and $342 \mathrm{~g} \mathrm{~kg}^{-1}$ total dry matter) in the diets of dairy heifers and observed that DM intake decreased linearly from the level of $119 \mathrm{~g} \mathrm{~kg}^{-1}$ onward, which was not observed in the present study. According to the author, this was due to the ether extract content and possibly due to the type of oil and the high lignin content present in this by-product.

According to Hartley (1977) in Furlan Júnior et al. (2006), the palm kernel cake contains $47.5 \%$ lauric acid and $16.4 \%$ myristic acid in its lipid composition. As stated by Palmquist and Mattos (2006), these acids have an amphiphilic nature, because they are soluble both in organic solvents and in water, thus are more toxic and have a greater intake-inhibition potential.

The intakes of NFC and TDN were not influenced $(\mathrm{P}>0.05)$ by the inclusion of palm kernel cake in the diets, averaging 65.9 and $99.9 \mathrm{~g} \mathrm{day}^{-1}$, respectively. Although alterations in the intakes of EE and CP were observed, TDN was not changed, which is due to the lack of alterations in NDFap and NFC.

Correia et al. (2012) evaluated the feeding behavior and physiological parameters of steers fed with biodiesel by-product cakes and observed a reduction in dry matter intake when the animals received palm cake in the diet, with no differences in NDF intake. According to the authors, this was a result of the high fiber content of the diet including palm kernel cake, which limited the feed intake due to the physical effect of the fiber.

The average intakes of CP and TDN were 19 and $99.9 \mathrm{~g} \mathrm{day}^{-1}$, respectively, which are higher values than 17.4 and $81.1 \mathrm{~g}$, respectively, recommended by NRC (2001) for cows producing $15 \mathrm{~kg}$ of milk with $3.5 \%$ fat.

Inclusion of palm kernel cake in the diet did not influence the digestibility coefficients of dry matter, crude protein, and ether extract $(\mathrm{P}>0.05)$ (Table 4). The EE digestibility may be a consequence of better digestibility of the EE present in the palm kernel cake. Increased digestibility may also occur depending on the level and type of the ether extract present in the palm kernel cake, which contributes to reducing digesta passage rates and increasing the time of exposure of the feed in the rumen and consequently digestibility of the fiber.

The digestibility of NDFap was not influenced by the addition of palm kernel cake in the $\operatorname{diet}(\mathrm{P}$ $>0.05)$. This response was because the NDFap ingredient mainly replaced sugarcane in the diet, reducing the NDFap from the latter, despite the high NDFap content of the cake (65.63\%).

There was no effect $(\mathrm{P}>0.05)$ of the treatments on the digestibility of NFC (89.05\%). Total digestible nutrients averaged $65.73 \%$, which is lower than the $70 \%$ level found by Bringel et al. (2011) in sheep diets with a higher concentration of palm kernel cake.

The supplementation levels of palm kernel cake in the diet had no effects on milk yield or feed efficiency $(\mathrm{P}>0.05)$; however, fat-corrected milk yield increased linearly $(\mathrm{P}<0.05)$ by 0.474 $\mathrm{kg}$ with every $1 \%$ of the ingredient added to the diet (Table 5). This result was likely due to the NDF levels present in the palm kernel cake, which increased with addition of palm cake to the diet. However, Cunha et al. (2012) evaluated the use of $0.00 \%, 11.34 \%, 22.78 \%$, and $34.17 \%$ palm kernel cake to dairy cows and observed a linear reduction $(\mathrm{P}<0.01)$ in milk yield and corrected milk yield. According to the authors, this outcome was due to the low non-fibrous carbohydrate content of palm kernel cake, which resulted in a lower content of total digestible nutrients. 
Table 4. Coefficient of digestibility of dry matter and nutrients of lactating cows fed with diets supplemented with varying levels of palm kernel cake.

\begin{tabular}{lcccccrr}
\hline \multirow{2}{*}{\multicolumn{1}{c}{ Digestibility (\%) }} & \multicolumn{3}{c}{ Palm kernel cake level $\left(\mathbf{g ~ k g}^{-1}\right)$} & \multirow{2}{*}{ Eq. } & CV \% & P-value \\
\cline { 2 - 5 } & $\mathbf{0 . 0 0}$ & $\mathbf{5 0 . 0 0}$ & $\mathbf{1 0 0 . 0 0}$ & $\mathbf{1 5 0 . 0 0}$ & & & \\
\hline Dry matter & 57.84 & 59.99 & 58.25 & 59.93 & 59.00 & 4.61 & 0.113 \\
Crude protein & 53.33 & 55.81 & 54.22 & 56.97 & 55.08 & 6.16 & 0.059 \\
Ether extract & 57.64 & 56.97 & 61.34 & 69.09 & 61.26 & 19.24 & 0.064 \\
NDFap & 67.88 & 38.37 & 39.12 & 38.24 & 39.94 & 10.41 & 0.409 \\
Non-fibrous carbohydrates & 88.22 & 89.63 & 89.08 & 89.29 & 89.05 & 2.01 & 0.269 \\
Total digestible nutrients & 64.98 & 66.45 & 64.95 & 66.54 & 65.73 & 4.10 & 0.298 \\
\hline
\end{tabular}

Eq. - regression equation; CV - coefficient of variation; NDFap - neutral detergent fiber corrected for ash and protein.

Table 5. Performance of lactating cows fed with diets supplemented with varying levels of palm kernel cake.

\begin{tabular}{lccccccc}
\hline \multirow{2}{*}{ Performance } & \multicolumn{3}{c}{ Palm kernel cake level } & \multirow{2}{*}{ Eq. } & \multirow{2}{*}{ CV \% } & P-value \\
\cline { 2 - 5 } & $\mathbf{0 . 0 0}$ & $\mathbf{5 0 . 0 0}$ & $\mathbf{1 0 0 . 0 0}$ & $\mathbf{1 5 0 . 0 0}$ & & & \\
\hline Milk yield (g day $^{-1}$ ) & 119.60 & 120.90 & 127.80 & 125.30 & 123.40 & 6.64 & 0.069 \\
Corrected milk yield (g day $\left.^{-1}\right)^{1}$ & 127.80 & 134.70 & 142.40 & 141.10 & 2 & 6.64 & 0.001 \\
Feed efficiency (kg milk DMI) & 0.82 & 0.81 & 0.81 & 0.82 & 0.82 & 6.00 & 0.997 \\
Body weight change (kg period) & 2.68 & 0.32 & 5.90 & 14.4 & 5.83 & 215.23 & 0.051 \\
\hline
\end{tabular}

Eq. - regression equation; CV - coefficient of variation; DMI - dry matter intake; ${ }^{13.5 \%}$ fat corrected milk yield; ${ }^{2} \hat{Y}=124.63+$ $0.474 x, R^{2}=0.84$.

Body weight change was not significantly $(\mathrm{P}>$ 0.05 ) affected by the inclusion of palm kernel cake in the diet. The coefficient of variation was high, because there was a very large variation in weight between the analyzed periods; heavier weights were obtained with the diet containing $15 \%$ palm kernel cake, which provided higher $\mathrm{CP}$ and EE intakes.

Of the milk components (Table 6), only fat content was affected $(\mathrm{P}<0.05)$ by the inclusion of palm kernel cake in the diet, which increased by 0.101 unit with every $1 \%$ of the cake added to the diet.

There was an increase in the dietary EE content with the inclusion of palm kernel cake in the diet, which might reduce the fat percentage of the milk considering that excess unsaturated fat in the diet can affect the rumen $\mathrm{pH}$, the fermentation of the vegetable fiber, and the proportion between butyric and acetic acids, precursors of fat. However, Barbosa et al. (2010) evaluated the inclusion of palm kernel cake in diets of bubaline animals on their rumen metabolism and observed that the acetate:propionate ratio increased with the addition of palm kernel cake, and that the palm kernel cake showed characteristics of a roughage rather than a concentrate. These characteristics of the palm kernel cake might have resulted in the increase of the rumen acetate:propionate ratio, with acetate being a precursor of the milk fat.

Milk protein, lactose, non-fat solids, and total solids were not affected by the inclusion of palm kernel cake in the diet (Table 6; $P>0.05$ ), because of the lower influence of the diet on these parameters. The values found in this study are within the established requirements for raw milk, according to the Technical Regulation of Identity and Quality of Refrigerated Raw Milk, which determined a minimum of $3.0 \%$ for fat, $2.9 \%$ for protein, and $8.4 \%$ for non-fat solids (BRAZIL, 2011). 
Table 6. Composition of the milk of lactating cows fed with diets supplemented with varying levels of palm kernel cake.

\begin{tabular}{lccccccc}
\hline \multirow{2}{*}{ Composition } & \multicolumn{3}{c}{ Palm kernel cake level $\left(\mathbf{g ~ k g}^{-1}\right)$} & \multirow{2}{*}{ Eq. } & \multirow{2}{*}{ CV \% } & \multirow{2}{*}{ P-value } \\
\cline { 2 - 5 } & $\mathbf{0 . 0 0}$ & $\mathbf{5 0 . 0 0}$ & $\mathbf{1 0 0 . 0 0}$ & $\mathbf{1 5 0 . 0 0}$ & & & \\
\hline Protein & 31.00 & 30.00 & 31.00 & 30.00 & 30.50 & 1.46 & 0.490 \\
Fat & 40.00 & 42.00 & 42.00 & 43.00 & 1 & 6.70 & 0.037 \\
Lactose & 46.00 & 46.00 & 46.00 & 46.00 & 46.00 & 1.47 & 0.467 \\
Solids nonfat & 84.00 & 83.00 & 84.00 & 83.00 & 83.50 & 1.47 & 0.447 \\
Total solids & 123.00 & 125.00 & 126.00 & 126.00 & 125.00 & 2.74 & 0.181 \\
\hline
\end{tabular}

Eq. - regression equation; $\mathrm{CV}$ - coefficient of variation; ${ }^{1} \hat{\mathrm{Y}}=3.905+0.101 \mathrm{x}, \mathrm{R}^{2}=0.83$.

\section{Conclusions}

Inclusion of palm kernel cake, up to $15 \%$, in the diet of dairy cows confined to receiving sugarcane with bulky did not influence the dietary intake or performance.

\section{References}

ABDALLA, A. L.; SILVA FILHO, J. C. DA; GODOI, A. R. DE; CARMO, C. A.; EDUARDO, J. L. P. Utilização de subprodutos da indústria de biodiesel na alimentação de ruminantes. Revista Brasileira de Zootecnia, Piracicaba, v.37, p. 260-258, 2008. Supplement.

BARBOSA, N. G. S.; RODRIGUEZ, N. M.; FERNANDES, P. C. C.; GARCIA, A. R. G.; NAHÚM, B. S.; SAliBA, E. S.; BORGES, I.; ÁVILA, S. C.; MENEZES, B. P.; RIBEIRO, O. A. V.; OLIVEIRA, M. E. C.; QUINZEIRO NETO, V. Intake and digestibility of river buffalo steers (Bubalus bubalis) fed different levels of palro kernel cake: Effect of diet neutral detergent fiber, digestible energy, crude protein and extract ether. Reveta Veterinária, Belém, v. 21, n. 1, p. 145-150, 2010. Supplement 1.

BRASIL. Instrução Normativa $n^{\circ} 62$, de 29 de dezembro de 2011. Regulamento técnico de produção, identidade e qualidade do leite tipo A leite cru refrigerado, leite pasteurizado e o regulamento técnico da coleta de leite Cru Refrigerado e seu transporte a granel. Diário Oficial [da] República Federativa do Brasil, Brasília, 30 dez. 2011. Seção 1:1-24.

BRINGEL, L. M. L.; NEIVA, J. N. M.; ARAÚJO, V. L.; BOMFIM, M. A. D.; RESTLE, J.; FERREIRA, A. C. H.; LÔBO, R. N. B. Consumo, digestibilidade e balanço de nitrogênio em borregos alimentados com torta de dendê em substituição à silagem de capim elefante. Revista Brasileira de Zootecnia, Viçosa, v. 40, n. 9, p. 19751983, 2011.

CORREIA, B. R.; OLIVEIRA, R. L.; JAEGER, S. M. P. L.; BAGALDO, A. R.; CARVALHO, G. G. P.; OLIVEIRA, G. J. C.; LIMA, F. H. S.; OLIVEIRA, P. A. Comportamento ingestivo e parâmetros fisiológicos de novilhos alimentados com tortas do biodiesel. Archivos de Zootecnia, São Gonçalo dos Campos, v. 61, n. 233, p. 79-89, 2012.

COSTA, D. A.; FERREIRA, G. D. G.; ARAUJO, C. V.; COLODO, J. C. N.; MOREIRA, J. R.; FIGUEIREDO, M. R. P. Consumo e digestibilidade de dietas com níveis de torta de dendê para ovinos. Revista Brasileira de Saúde e Produção Animal, Belém, v. 11, n. 3, p. 783-792, 2010.

CUNHA, O. F. R.; NEIVA, J. N. M.; MACIEL, R. P.; MIOTTO, F. R. C.; NEIVA, A. C. G. R.; RESTLE, J. Avaliação bioeconômica do uso da torta de dendê na alimentação de vacas leiteiras. Ciência Animal Brasileira, Goiânia, v. 13, n. 3, p. 315-322, 2012.

DETMANN, E.; SOUZA, M. A.; VALADARES FILHO, S. C.; QUEIROZ, A. C.; BERCHIELLI, T. T.; SALIBA, E. O. S.; CABRAL, L. S.; PINA, D. S.; LADEIRA, M. M.; AZEVEDO, J. A. G. Métodos para análise de alimentos. Visconde do Rio Branco: Instituto Nacional de Ciência e Tecnologia de Ciência Animal-INCT, Suprema, 2012. 214 p.

DETMANN, E.; VALADARES FILHO, S. C. On the estimation of non-fibrous carbohydrates in feeds and diets. Arquivo Brasileiro de Medicina Veterinária e Zootecnia, Viçosa, v. 62, n. 4, p. 980-984, 2010.

FURLAN JÚNIOR, J.; KALTNER, F. J.; AZEVEDO, G. F. P.; CAMPOS, I. A. Biodiesel: porque tem que ser dendê. Belém: Embrapa Amazônia Oriental; Palmasa, 2006. 205 p. 
HARTLEY, C. W. S. The oil palm. $2^{\text {th }}$ ed. London: Longmans, 1977. 824 p.

MACIEL, R. P.; NEIVA, J. N. M.; ARAUJO, V. L.; CUNHA, O. F. R.; PAIVA, J.; RESTLE, J.; MENDES, C. Q.; LÔBO, R. N. B. Consumo, digestibilidade e desempenho de novilhas leiteiras alimentadas com dietas contendo torta de dendê. Revista Brasileira de Zootecnia, Tocantins, v. 41, n. 3, p. 698-706, 2012.

MERTENS, D. R. Regulation of forage intake. In: FAHEY, J. F. G. C. (Ed.). Forage quality evaluation and utilization. Madison: American Society of Agronomy, Inc., Crop Science Society of America, Inc., Soil Science of America, Inc., Wisconsin, USA, 1994. p. 450-493,

NATIONAL RESEARCH COUNCIL - NRC. Nutrient requirements of dairy cattle. $7^{\text {th }}$ ed. Washington: National Academic Press, 2001. 381 p.

PALMQUIST, D. L.; MATTOS, W. R. S. Metabolismo de lipídeos. In: BERCHIELLI, T. T.; PIRES, A. V.; OLIVEIRA, S. G. (Ed.). Nutrição de ruminantes. Jaboticabal: Funep, 2006. p. 287-310.

PREGNOLATO, W.; PREGNOLATO, N. P. Métodos químicos e físicos para análise de alimentos. In: Pregnolato. Normas analíticas do Instituto Adolfo Lutz. 3. ed. São Paulo: Instituto Adolfo Lutz, v. 1, 1985. 533 p.

SISTEMA PARA ANÁLISES ESTATÍSTICAS - SAEG. SAEG: sistema para análises estatísticas, versão 9.1. Viçosa: UFV, 2007.
SANTOS, J. F.; DIAS JÚNIOR, G. S.; BITENCOURT, L. L.; LOPES, N. M.; SIÉCOLA JÚNIOR, S.; SILVA, J. R. M.; PEREIRA, R. A. N., PEREIRA, M. N. Resposta de vacas leiteiras à substituição parcial de farelo de soja por ureia encapsulada. Arquivo Brasileiro de Medicina Veterinária e Zootecnia, Castrolanda, v. 63, n. 2, p. 423432, 2011.

SILVA, J. F. C.; LEÃO, M. I. Fundamentos de nutrição dos ruminantes. Piracicaba: Livroceres, 1979. 235 p.

SKLAN, D.; ASHKENAZI, R.; BRAUN, A.; DEVORIN, A.; TABOR, K. Fatty acids, calcium soaps of fatty acids, and cottonseeds fed to high yielding cows. Journal of Dairy Science, Rehovot, v. 75, n. 9, p. 2463-2472, 1992.

SOUZA, B. M.; SATURNINO, H. M.; BORGES, A. L. C. C.; LOPES, F. C. F.; SILVA, R. R.; CAMPOS, M. M.; PIMENTA, M.; CAMPOS, W. E. Estimativa de consumo de matéria seca e de fibra em detergente neutro por vacas leiteiras sob pastejo, suplementadas com diferentes quantidades de alimento concentrado. Arquivo Brasileiro Medicina Veterinária Zootecnia, Leandro Ferreira, v. 60, n. 4, p. 890-895, 2008.

SUE, T. T. Quality and Characteristics of Malaysian Palm Kernel Cakes/Expellers. Palm Oil Development, Kuala Lumpur, v. 34, n. 1, p. 1-3, 2001.

VALENTE, T. N. P.; DETMANN, E.; QUEIROZ, A. C.; VALADARES FILHO, S. C.; GOMES, D. I.; FIGUEIRAS, J. F. Evaluation of ruminal degradation profiles of forages using bags made from different textiles. Revista Brasileira de Zootecnia, Viçosa, v. 40, n. 11 , p. 2565-2573, 2011. 
